\title{
The Theory of Yellow Peril and a New Yellow Peril Caused by COVID-19
}

\author{
Yifei $\mathrm{Wu}^{1, *}$ \\ ${ }^{1}$ Indiana University, Bloomington, Indiana, 47406, USA \\ *Corresponding author. Email: yw106@iu.edu
}

\begin{abstract}
The essay explores how the yellow peril has formed and spread in the US, especially during the COVID-19. This phenomenon was observed in the $19^{\text {th }}$ century and has been serious again during the COVID-19. It has resulted in serious problems for Chinese people in the US or Chinese people who want to go to the US. The essay uses a case study. Through the case study of the yellow peril in the US, the essay hopes to understand the spread of the yellow peril from media and international political influences. The essay's result reveals that the yellow peril's spread is related to media and political influences. From the media side, people deal with the media every day, so what kind of content the media plays greatly impacts Americans' subconscious view of Asians. The influence of the media has led to Americans' extreme views on Asians. From the political side, the relationship between two countries and the competition between two countries also influence the spread of yellow peril. In conclusion, the essay deepens our understanding of yellow peril and its media and political influences in the US. Moreover, Asian people's mental health and physical damage also got influenced by the yellow peril. Admittedly, the essay is limited in that it only looks at the case of the yellow peril in the US. Also, the paper mainly explains yellow peril from the media and political perspectives. Further studies can look into the yellow peril reality in other countries. The research can also explain the yellow peril from other perspectives, like economic, cultural, and social perspectives.
\end{abstract}

Keywords: The Yellow Peril, COVID-19, Origin, Political Influence, Media Influence, Asians, Mental Health, Physical Damage

\section{INTRODUCTION}

The essay's focused how the yellow peril has formed and spread in the US, especially during the COVID-19. This research question is puzzling because the yellow peril is serious in the US, especially during COVID-19. This reality has not been researched in detail. This question is complex and unique because the US is a country that started by immigration. Also, today is the era of globalization, especially under the damage of the COVID-19, the United States should cooperate with many countries to ensure its development. Therefore, it is highly surprising that the yellow peril is so serious under the damage of the COVID-19.

In 1875, the page act announced that American employers were prohibited from hiring Chinese coolies to work in the United States [1]. In the name of protecting Chinese workers, it did not welcome Chinese people to make a living in the United States. In 1882, the US Congress passed the Chinese Exclusion Act.
This move had pushed the Chinese exclusion policy to a new height. The act stipulated that all workers from China engaged in skilled or unskilled labor shall not enter the United States, almost excluding all Chinese who wanted to work in the United States. Chinese immigrants who had settled in the United States also needed to obtain a new entry permit if they re-entered the United States after leaving the United States [2]. For Chinese who were lucky enough to come to the United States and want to naturalize in the United States, becoming American citizens had become impossible because the Chinese Exclusion Act prohibited Chinese from acquiring American citizenship. The Chinese Exclusion Act of 1882 was the only act prohibiting single ethnic immigrants to the United States, which was not repealed until 1943. With racism and the exaggeration of the "Yellow Peril theory", Americans were more and more hostile to Asians and Chinese. Although racial discrimination is no longer widely accepted today, this indelible history still impacts the lives of Chinese in the United States. According to the immigration act of 1924, it completely excluded Asian 
immigrants, and there were only 100 immigrants in China in 1924, which was the lowest [3]. These two factors can show us why Chinese immigrants were heavily racialized. Nowadays, it is still difficult for Chinese people who want to immigrate to the United States and obtain recognition. The yellow peril enters a new height in the US during the term of COVID-19.

This essay will focus on the case of the yellow peril in the US. The US is a unique case because it is a contradiction between a country that started by immigration and the uncontrollable spread of yellow peril during COVID-19. This case applies to other countries with the same situation, and there is an impact on mental health and physical damage for Asian people.

This topic matters because it deepens our understanding of the yellow peril and the factors of its spread. It has influenced Asians in the US. It can be useful to policy recommendations or others to relieve the problem.

The essay is divided into several sections. After the introduction, the paper will discuss the origin of the yellow peril theory. Next, the paper will look at the media influence on Asian hate during COVID-19 in the US. The essay will then analyze how political influence impacts the yellow peril generation during COVID-19 in the US. The essay will subsequently review how the yellow peril influences Asian people's mental health and physical damage. The findings in this research offer indepth insights into understanding human behavior and racial problems and shed light on further studies.

\section{THE ORIGIN OF YELLOW PERIL THEORY}

"Yellow Peril theory" originated from a European theory against Asian yellow people such as China and originated from the fear of the European race caused by the Asian invasion into Europe. Yellow peril is an extreme nationalist theory formed in the 19th century. The "Yellow Peril theory" holds that the white race is the best in the world, while the Chinese are the worst race among all races created by God, so they naturally have a sense of superiority. The theory advocates that the yellow people are a threat to the white people, and the white people should unite against the yellow people. The "Yellow Peril theory" advocates tried their best to belittle and distort Chinese culture and despise it as inferior culture. At the end of the 19th century and the beginning of the 20th century, the "Yellow Peril theory" was rampant, pointing at China, Japan and other countries.

After the Sino-Japanese War of 1894-1895, western countries represented by German Emperor William II set off the first wave of "Yellow Peril theory". They advocated that yellow races such as China posed a threat to white races in the west, trying to justify the invasion and oppression of China by Western powers.
German Emperor William II even concocted the poster yellow peril, which greatly responded in both eastern and Western societies.

\section{MEDIA INFLUENCE ON ASIAN HATE DURING COVID-19}

This section will analyze how the media causes Asian hate in the US. According to the research of the relationship between prejudice toward Chinese and social media in integrated threat theory, as the US government has repeatedly reported the message that the COVID-19 is from China through media since January 2021, the anti-Asian sentiment has begun to grow [4]. Because the spread of COVID-19 has been fast in the US, more and more people stop their studies or work to stay at home, so the connection between people and social media has increased. In the research, we can see that these public media opinions have led the report of anti-Asians to spread so fast and widely, and there are also more and more Asian-Americans have used media to fight for the hate [4]. It means that the media's content has a great impact on Americans' view of Asians. The influence of the media has led to Americans' extreme views on Asians. For example, 167 countries use national portals and social media platforms to engage people and provide vital information against COVID-19 [5]. Consequently, social media plays a very important role in people's cognition and influences their communication during this special time [6].

According to the research, social media can influence people because they think most people use are credible, fair, and accurate. When these platforms report more negative news of the Chinese, more users believe that the Chinese pose a real threat to the US [4]. Also, the people who depend on social media to get the message of the world have greater trust in social media than those who do not often use social media, so if the social media report something every day, it can let people have a deep memory of that. From these, I think the Asian hate is also like this explains. Because social media often report negative news or public opinions about China, people have a deep memory of them in their mind, and these are from the dependable platforms they think, so their hate for Asians has increased.

\section{POLITICAL INFLUENCE ON YELLOW PERIL GENERATION DURING COVID-19}

\subsection{The Political Situations Between China and The US Cause the Yellow Peril During COVID-19}

The different social systems and groups between the US and China caused the necessary relationship between these two countries. It influences the policies and attitude of the US for Chinese people in the US or 
Chinese people who want to go to the US. According to major differences between China and the US, China and the US are completely different systems. It is one of the biggest differences [7]. The US is a capitalist country, and China is a socialist country. This major difference between China and the US shows that these two systems are opposite on some sides [7]. The different systems and their opposition often lead to contradictions between the two countries, explaining why the US is not friendly with the Chinese. In Fall 2020, the US government did not allow Chinese communists and their families to enter the US in a period. Recently, more and more Chinese students are asked, ' Are you a communist when they enter the customhouse, even if many students cannot enter the customhouse more than 20 hours.

In recent years, the competition between the US and China also caused the necessary relationship between these two countries. It also affects Chinese people in the US or Chinese people who want to go to the US. In terms of the change of international status, from the birth of the US to the present, the international status of the United States has been rising, and now it may be facing the first decline in history; China's international status has fluctuated, especially since modern times. According to the article of Yao Li, Harvey L, and Nicholson Jr, more recently, the international status of China is more and more big and wide in the world, with the rise of China and the increasingly intensified USChina competition, the target to blame has shifted from Japan to China [8]. These differences have an important impact on the concepts and mentality of the two countries. Both sides cannot help judging each other according to their own values and experience in exchanges. Recently, some American political advertisements accused China of stealing American manufacturing jobs and imagined Chinese students and professors laughing at the collapse of the US [9, 10]. These political advertisements have greatly distorted China and caused Americans to be hostile to the Chinese people. According to the seven critical questions for strategy, due to the fast development in every side of China and the competition in every side and the competition of the world power between China and the US in recent years, the US has more and more strict control over Chinese immigration and visas, the competition of two strong countries also leads the contradictions between each other [11]. In recent years, especially during COVID-19, the US government has stopped some Chinese students' visas and refuses to issue visas to some Chinese students because Chinese citizens and Chinese Americans are spies who come to the United States to steal technology [8]. A study finds that the Department of Justice disproportionately charges Chinese and other Asian Americans-no matter guilty or innocent - with espionage [12]. The Chinese seem to be divided into one category, one that needs strict control and review. This factor makes the Chinese people are heavily racialized.

\subsection{American Inner Political Competition Causes the Yellow Peril During COVID-19}

As we all know, the United States uses a two-party system. The ruling philosophy of the Republican Party is different from that of the Democratic Party. During COVID-19, it caught up with the US 2020 presidential election. The American people did not maintain social distance to vote for their president, which led to a serious epidemic. Also, Presidential candidates ignored the issue of social distance in order to win votes for themselves, which led to the rising of the danger of the spread of COVID-19. According to AJMC, on June 10, the US COVID-19 Cases had reached 2 million [13]. AJMC continued to report that the US COVID-19 Cases had reached 3 million on July 7 . The speed of growth was fast [14]. In another hand, the serious division of American society and the different attitudes of the two parties and American people towards defending COVID-19 have led to a sustained rise in death toll and infection rate. Dan Goldberg and Alice Miranda Ollstein show there is a partisan divide in vaccinations in their research. Partisan divided is becoming starker in vaccinations [15]. However, to divert people's attention and win the election for himself, Trump united with some European countries to release the news that the virus came from China to the public. In addition, the US government has formulated various measures to curb China's development. Like these, the anger and attention of the American people have shifted to China. Because American people have received negative news about China every day, the image of the Chinese is also not good in their minds.

\section{PHYSICAL AND MENTAL INFLUENCE ON ASIANS}

\subsection{The Relevant Measures of The US Society for Asians}

It has been 200 years since Chinese immigrants started to emigrate to the United States in 1820. At first, the Chinese were to avoid starvation, war and corruption in China, so they emigrated to the US. Now, most Chinese immigrants are to change a life to get more opportunities from education or employ the US. For example, the economic opportunities abroad like the California gold rush, which occurred in 1849. Chinese immigrants have been excluded from the economy, politics and society of the United States for 200 years, but with different degrees and emphases in different terms. Because of the differences between China and the United States in all aspects, Chinese immigrants are always regarded as racists and are heavily racialized by the US society [7].

In different periods, there are different measures for Asians. For example, the process during the late-19th 
century to mid- $20^{\text {th }}$ century that prohibited Chinese employees from controlling Chinese people entered the US to completely exclude Asians immigrations [1-3]. In recent years, through the development of China and the necessary relationship between China and the US, there have been more detailed measures for Asians. For example, controlling Chinese immigrations visas [11], stopping and controlling Chinese students' visas [8], restricting some Chinese people from entering the US, such as Communists. Also, the American government is deliberately warping the image of China and the Chinese people in the eyes of Americans $[9,10]$. Like these, we can see that the United States is trying to limit and exclude the Chinese people on many sides no matter what period.

\subsection{Physical And Mental Damage for Asians}

During the COVID-19, due to the presidential election, the poor relationship between China and the United States, and the hype of the government or relevant people, the discrimination and exclusion of Asian Americans in the United States has pushed to a new height. Since the COVID-19 outbreak in Wuhan, China, in early 2020, anti-Asian discrimination has increased [8]. Asian Americans from all walks of life, including the presidential candidate, journalists, college professors, students, and supermarket cashiers, have become the target of racial hostility. [8] On the front lines fighting the coronavirus, doctors and nurses of Asian ancestry have heard verbal slurs or patients refuse treatment from Asian professionals [16]. As people have avoided Chinatowns since the outbreak, Asian businesses have also been hit hard, with many being shut down; as a result, the unemployment rate among Asians is skyrocketing [17]. Sinophobia and hostility against Asians also surged in social media, including Twitter and 4chan [18]. Even there is some violence, like Americans beating up Chinese people in the street or subway station, but other people turn a blind eye to it. This kind of thing has happened frequently during the COVID-19, there are more than once. Like this, Chinese people meet the physical damage from the American society and American people. From mental damage, the economic anxiety caused by unemployment and the exclusion of Chinese people in all aspects will constitute psychological pressure and imbalance, the violence from American people also can cause the mental damage. Of course, the "Wuhan virus" has added an unintentional burden to the hearts of the Chinese people, whether it is true or not. Because the spread of public opinion that the virus comes from China and related to Chinese bad eating and health habits has further aroused the hatred of Americans towards the Chinese people $[19,20]$.

\section{CONCLUSION}

In summary, the essay firstly has introduced the origin of the yellow peril theory. Then it has looked at the media influence on Asian hate during COVID-19. After that, the essay has analyzed the political influence on the yellow peril generation during COVID-19. Following that, the analysis has reviewed how yellow peril influences Asians on physical and mental damage.

The essay deepens our understanding of yellow peril and how it formed and spread from media and political sides, it also deepens our understanding of how yellow peril influences Asians from physical and mental sides. It can be useful to policy recommendations or others to relieve the problem.

The essay has several limitations. The analysis may be incomplete, and maybe there are other influences on yellow peril generation from economic, cultural, social perspectives. The single case provides limited explanation and may not fully explain other cases.

Future studies can focus on other cases. Also, to fully understand the phenomenon, it is worthwhile to explore other perspectives and reasons.

\section{REFERENCES}

[1] FORTY-THIRD CONGRESS. The Page Act of 1875. (Immigration Act). (March 3, 1875).

[2] US Department of State. (n.d.). Chinese Immigration and the Chinese Exclusion Acts. US department of state.

[3] US Department of State. (n.d.). The Immigration Act of 1924 (The Johnson-Reed Act). US department of state.

[4]Stephen, M. C. Nguyen, T. \& Rahmani, D. 12 June 2020. Prejudice Toward Asian Americans in the COVID-19 Pandemic: The Effect of Social Media Use in the US.

[5] United Nation (2020). UN/DESA policy brief \#61: Covid-19: Embracing digital government during the pandemic and beyond.

[6] Schultz, F., Utz, S., and Göritz, A. (2011). Is the. medium the message? Perceptions of and reactions to crisis communication via twitter, blogs and traditional media. Public Relat. Rev. 37, 20-27. doi: 10.1016/j.pubrev.2010.12.001

[7] Graf, R. (March 20, 2019). 13 Major Cultural Differences Between China and the US.

[8] Yao Li, Havey L. Nicholson Jr., (January 16 2021) When "model minorities" become "yellow peril"Othering and the racialization of Asian Americans in the COVID-19 pandamic. DOI: 
https://onlinelibrary.wiley.com/doi/full/10.1111/so c4.12849

[9] Chin, J. (2010). Fear mongering 101: Anti-China campaign ads. Wall Street Journal.

[10] Weiner, R. (2012, February 6). Pete Hoekstra's China ad provokes accusations of racism. The Washington Post.

[11] Hass, Ryan \& Rapp, M. H. (February, 2019). Responsible competition and the future of USChina relations: Seven critical questions for strategy.

[12] Kim, A. C. (2018). Prosecuting "Chinese Spies": Empirical analysis of economic espionage. Cardozo Law Review, 40(2).

[13] AJMC, June 11, 2020. 'What We're Reading: Black Youth Mental Health Tested; COVID-19 Cases Top 2 Million; Nursing Homes Seizing Stimulus Checks.'

[14]. AJMC, July 8, 2020. 'What We're Reading: 3 Million US COVID-19 Cases; US Withdraws From WHO; HIV Long-Acting Injectable.'

[15] Dan Goldberg and Alice Miranda Ollstein. (2021). 'The partisan divide in vaccinations is starker than you realize'

[16] Jan, T. (2020). Asian American doctors and nurses are fighting racism and the coronavirus. Washington Post.

[17] Liao, S. (2020, May). Unemployment. claims from Asian Americans have spiked 6,900\% in New York. Here's why. CNN Business.

[18] Schild, L., Ling, C., Blackburn, J., Stringhini, G., Zhang, Y., \& Zannettou, S. (2020). "Go eat a bat, Chang!": An early look on the emergence of sinophobic behavior on Web communities in the face of COVID-19.

[19] Zhang, L. (2020, February 16). Coronavirus. triggers an ugly rash of racism as the old ideas of 'Yellow Peril' and 'sick man of Asia' return. South China Morning Post.

[20] Zhang, J. G. (2020). Pinning coronavirus on how Chinese people eat plays into racist assumptions. Eater. 